\title{
A new species of the genus Candonopsis (Crustacea, Ostracoda) from Western Australia
}

\author{
Ivana Karanovic \\ University of Tasmania, School of Zoology, Private Bag 5, Hobart, Tasmania 7001, Australia
}

\begin{abstract}
A new species of stygobiont ostracod, Candonopsis (Abcandonopsis) limnaci sp. nov, is described from subterranean waters of the Murchison region in Western Australia. The new species can be easily distinguished from other representatives of the genus by 6-segmented antennula and incompletely divided penultimate segment of the walking leg. A key to the representatives of the genus Candonopsis in Australia is also provided.
\end{abstract}

Key words: Abcandonopsis, Candonopsini, taxonomy, stygobiont Ostracods, key to species

\section{INTRODUCTION}

The genus Candonopsis Vávra 1891 was recently revised by Karanovic (2004), who synonymized three species and brought the total number to 24. Karanovic (2007) described another three new species from subterranean waters of the Pilbara region in Western Australia. The genus is currently divided into two subgenera: Candonopsis s. str. and Abcandonopsis Karanovic 2004 (see Karanovic 2004). The nominotypical subgenus has the following five species in Australia: Candonopsis (C.) tenuis (Brady 1886), C. (C). murchisoni Karanovic and Marmonier 2002, C. (C.) dani Karanovic and Marmonier 2002, C. (C.) kimberleyi Karanovic and Marmonier 2002 and C. (C.) westaustraliensis Karanovic and Marmonier 2002. The first species was reported from New South Wales (Brady 1886; Sars 1896) and Western Australia (Karanovic 2007; Karanovic and Marmonier 2002), and I have also found it in a sample from Queensland (unpublished data). Candonopsis tenuis is also reported from Sumatra (Klie 1932). Candanopsis murchisoni, C. dani and C. westaustraliensis were described and only known from the Murchison region, while C. kimberleyi is endemic to the Kimberley region. The subgenus Abcandonopsis also has six species in Australia: C. (A.) williami Karanovic and Marmonier 2002, C. (A.) aula Karanovic 2004, C. (A.) indoles Karanovic 2004, C. (A.) dedeckkeri Karanovic 2007, C. (A.) inaffecta Karanovic 2007 and C. (A.) pilbarae Karanovic 2007. The first species, which is the type species of the subgenus, was described from the Murchison region in Western Australia. The following two species were described from the Kimberley, while the last three species were reported from the Pilbara region. Except for C. (C.) tenuis, which can be found in springs as well as in subterranean waters, all the other species of the genus Candonopsis in Australia are stygobionts. In the present paper, one other species of the subgenus Abcandonopsis collected from boreholes in the Murchison region is described.

The genus Candonopsis has its greatest diversity in the southern hemisphere. In the northern hemisphere the genus is generally regarded as a Tertiary relict (Danielopol 1980a), with six species mainly living in the underground waters of Europe (Karanovic and Marmonier 2002). While the subgenus Abcandonopsis is endemic to Australia, the nominotypical subgenus is distributed in Central America, Africa, India, Sumatra, Java, Solomon Islands and Australia (Karanovic 2004), where the species live predominantly in surface waters. However, almost all of the species have a restricted distribution. This is also the case with other genera of the tribe Candonopsini, to which Candonopsis belongs. Cubacandona Broodbakker 1983 and Caribecandona Broodbakker 1983 are known from Cuba and West Indies (Broodbakker 1983; Danielopol 1980a), Marococandona Marmonier, Boulal and Idbennacer 2005 from Morocco and Pioneercandonopsis Karanovic 2005a from Queensland. I have another new genus, with at least six species from New South Wales, which is awaiting description (Karanovic, unpublished data). With the addition of the new species described here, the genus Candonopsis presently has 12 living species in Australia, the majority of them being short-range endemics in the Murchison and Pilbara regions. Therefore, Australia may be considered to be the center of biodiversity for the 
genus Candonopsis, and maybe even for the entire tribe Candonopsini.

\section{MATERIAL AND METHODS}

Samples were taken from bores using plankton net of suitable diameter $(47 \mu \mathrm{m}, 97 \mu \mathrm{m}, 147 \mu \mathrm{m}$, or $197 \mu \mathrm{m})$ to match the bore. The net, with a weighted McCartney vial attached, was lowered to the base of the bore and then agitated up and down couple of times to disturb the bottom. Entire samples were preserved in $100 \%$ ethanol.

Specimens were dissected and mounted on microscope slides in Faure's medium, which was prepared following the procedure of Stock and Vaupel Klein (1996), and dissected appendages were then covered with a coverslip. All drawings were prepared using a drawing tube attached to a Leica DMLS bright-field compound microscope with C-PLAN achromatic objectives. Specimens that were not drawn were examined in a mixture of equal parts of distilled water and glycerol and, after examination, were again preserved in $70 \%$ ethanol. All examined material is deposited in the Western Australian Museum (WAM).

Terminology of A1 follows Karanovic (2005b). Martens (1987) revised the terminology for A2 given originally by Broodbakker and Danielopol (1982). The present paper follows Martens (1987) except that the short claw on the male terminal segment is considered to be homologous with the female GM claw, while the long one is homologous with the female Gm claw. This is because GM claw is situated internally, while Gm is inserted externally. The terminology for the Md follows Broodbakker and Danielopol (1982), and for the T3 Meisch (1996). Lobes on the hemipenis are labeled according to Danielopol (1969).

\section{SYSTEMATICS}

\section{Family Candonidae Kaufmann 1900}

\section{Subfamily Candoninae Kaufmann 1900}

Tribe Candonopsini Karanovic 2004

\section{Genus Candonopsis Vávra 1891}

\section{Subgenus Candonopsis (Abcandonopsis) Karanovic 2004}

Candonopsis (Abcandonopsis) linnaei sp. nov. Figures 1-3

\section{Material examined}

Holotype

Australia: Western Australia: d, Murchison region, Lake Way, bore NLV 16, 26 50'4"S, $120^{\circ} 19^{\prime} 38^{\prime \prime} \mathrm{E}, 19$ July 2007, collected by staff from Outback Ecology (Perth) (WAM C35715, dissected on one slide) [ecological data: water depth $=3.7 \mathrm{~m}$;
$\mathrm{pH}=7.8$; Salinity $=5.9 \mathrm{ppt}$; Electrical Conductivity $=10.48 \mathrm{mS} / \mathrm{cm} ; \mathrm{t}=23.7^{\circ} \mathrm{C}$; Dissolved Oxygen $=$ $7.03 \mathrm{ppm}$.

\section{Paratype}

Australia: Western Australia: 1 d, collected with holotype (WAM C35716, in alcohol).

\section{Other material}

Australia: Western Australia: 1 q Murchison region, Lake Way, bore NVCT0612, 26 50'46"S, $120^{\circ} 21^{\prime} 47^{\prime \prime} \mathrm{E}, 17$ July 2007, collected by staff from Outback Ecology (Perth) (WAM C35717, dissected on one slide) [ecological data: water depth $=1 \mathrm{~m} ; \mathrm{pH}=7.55$; Electrical Conductivity $=65.70 \mathrm{mS} / \mathrm{cm} ; \mathrm{t}=21.9^{\circ} \mathrm{C} ;$ Dissolved Oxygen $=$ 7.43 ppm]; 1 ?. (WAM C35718, dissected on one slide), Murchison region, Lake Way, bore NLW18, 26ㅇ' $19^{\prime \prime}$ S, 120 19'41'E, 19 August 2007, collected by staff from Outback Ecology (Perth) [ecological data: water depth $=4.5 \mathrm{~m} ; \mathrm{pH}=7.4$; salinity $=$ $60.50 \mathrm{ppt}$; Electrical Conductivity $=85.40 \mathrm{mS} /$ $\mathrm{cm} ; \mathrm{t}=25^{\circ} \mathrm{C}$; Dissolved Oxygen $\left.=5.28 \mathrm{ppm}\right] ; 1$ ㅇ, 3 disintegrated $\delta$ and 3 disintegrated juveniles (WAM C35719, in alcohol).

\section{Diagnosis}

Valves asymmetrical. Left valve larger than right valve, anterior and ventral margin connected at almost right angle. Antennula 6-segmented. Walking leg without basal seta; cleaning leg without Tf seta. Both claws on caudal ramus well developed, hemipenis with triangular lobe " $a$ ", genital field rounded.

\section{Description}

\section{Male (holotype)}

Length of carapace $0.66 \mathrm{~mm}$. Greatest height around middle, equaling $50 \%$ of total length. Carapace asymmetrical (Figure 1B) with left valve overlapping right valve on all free margins. Left valve with anterior and ventral margin connected at almost right angle, while same margin rounded on right valve. Dorsal margin on both valves straight in the middle, rounded towards posterior end, and inclined towards anterior (Figure 1A). Ventral margin concave in the middle. Marginal pore canals very short, straight, and more dense anteriorly. Inner calcified lamella broad, equaling $25 \%$ of total length anteriorly and $20 \%$ posteriorly. Surface of carapace smooth with sparse setae.

Antennula (Figure 2C, D): 6-segmented. First segment representing fused coxa and basis. Exopod reduced to two setae (Ex1 and Ex2). Both setae on coxobasis present (CB1 and CB2). Endopod 5-segmented. First, fourth, fifth and sixth segments free; second and third segments 


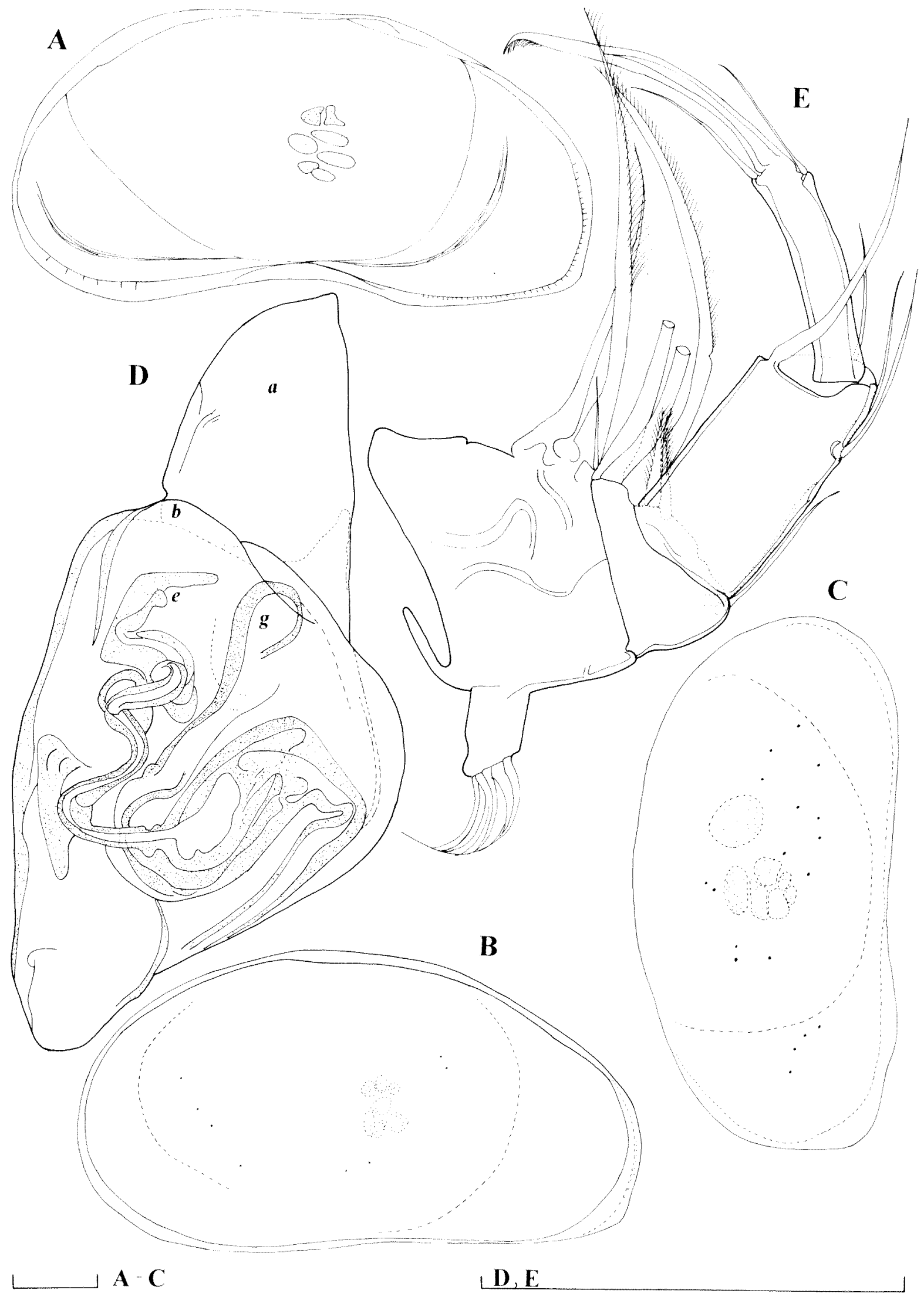

Figure 1 Candonopsis linnaei sp. now. A, B, D, E, holotype male; C, female $(0.63 \mathrm{~mm})$ : A, left valve, internal view $B$, carapace, lateral view from the right side; C, carapace, lateral view from the left side; D, hemipenis; $E$, mandibular palp. Scale lines $=0.1 \mathrm{~mm}$. 


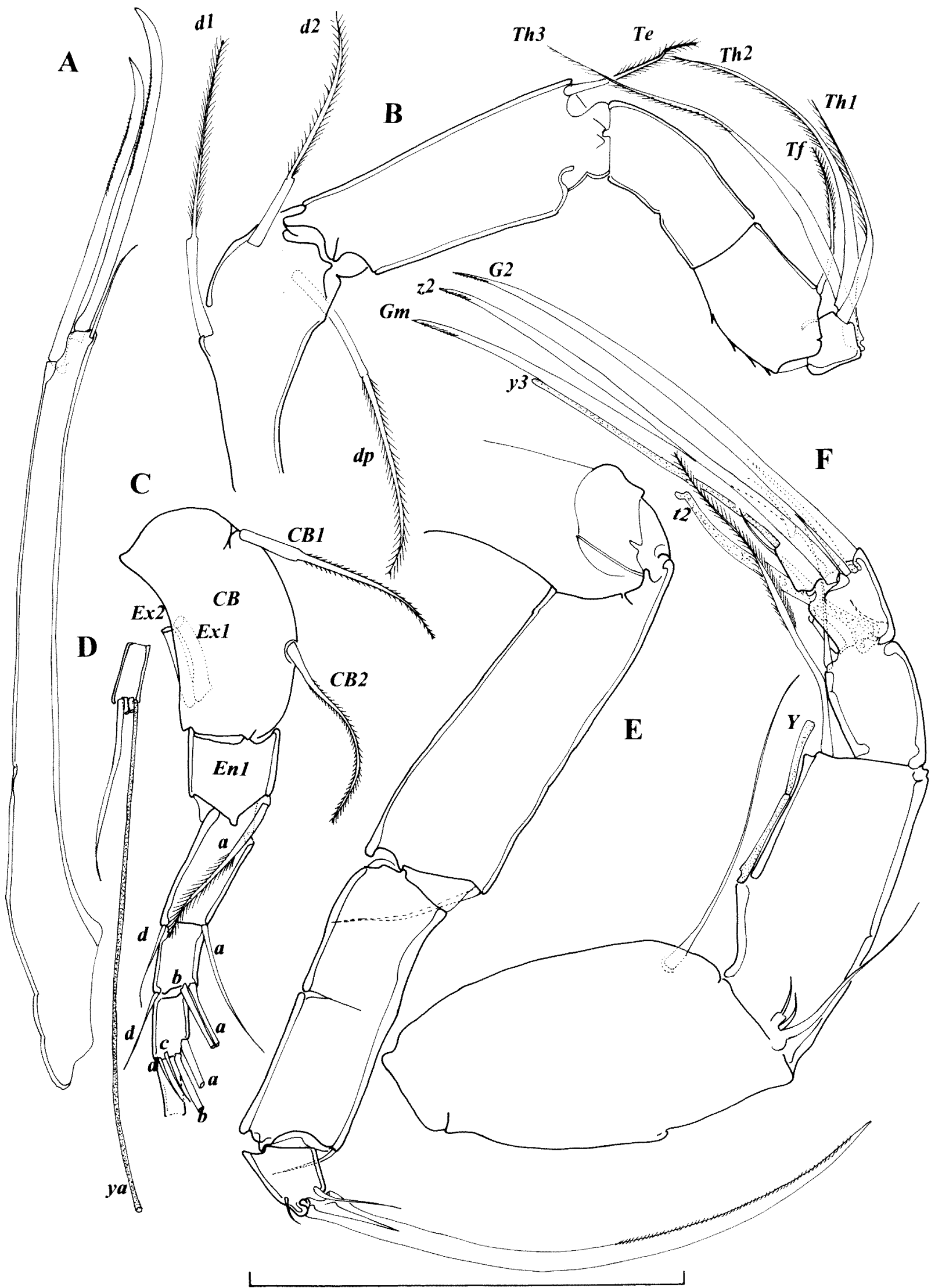

Figure 2 Candonopsis linnaei sp. nov., holotype male: A, caudal ramus; B, cleaning leg; C, antennula; D, terminal segment of antennula; E, walking leg; F, antenna. Scale lines $=0.1 \mathrm{~mm}$. 
fused. First segment with one anterior seta ("a") which pappose and overpassing distal margin of fused second and third segments. Fused segments with one anterior seta "a", extending beyond distal margin of penultimate segment, and posterior seta " $\mathrm{d}$ " extending beyond distal margin of following segment. Fourth endopodal segment with two long anterior setae ("a" and " $b$ ") and one short posterior seta "d" which extending beyond distal margin of fifth segment. Fifth segment with both anterior setae and posterior setae present. Posterior setae short, anterior ones long. Terminal segment with posterior seta 2.9 times longer than same segment, two long setae, and aesthetasc ya, which eight times longer than terminal segment. Length ratio of endopodal segments equaling 1.5 $: 2.3: 1.15: 1: 1$.

Antenna (Figure 2F): exopod consisting of a plate with two short and one long seta. Second endopodal segment subdivided and with two male bristles ( 2 and $t 3$ setae) present. Seta $z 1$ short only slightly overpassing terminal segment, seta $z 2$ transformed into long claw, which 1.8 times longer than first endopodal segment. Claw G2 as long as 22; claws G1 and G3 reduced; first one about two times longer than terminal segment, latter transformed into seta and only slightly shorter than G2. Claw GM on terminal segment reduced and about as long as terminal segment, claw Gm well developed and 1.6 times longer than first endopodal segment. Aesthetasc Y 0.6 times as long as first endopodal segment, y3 approximately as long as same segment. Length ratios of endopodal segments equaling $4.4: 1.8$ : 1.4 .

Mandibula (Figure 1E): exopod with numerous short rays. Basal segment with both " $S$ " setae well developed and pappose and with short alpha seta. Following segment with two outer setae, reaching middle of following segment, and $3+2$ setae in inner bunch. Three setae pappose and long, beta seta and other short seta plumped. Penultimate segment with two outer setae not reaching middle of terminal segment, one distal seta and one inner distal seta which almost reaching middle of terminal claw. Terminal segment elongated 4.5 times longer than wide. Terminal claw fused with segment and accompanied with two thin setae on each side, subequally long and reaching middle of terminal claw.

Maxillula (Figure 3F): palp with four pappose setae on penultimate segment. Same segment wide and with distal row of small setae. Terminal segment with three claws and one seta.

Prehensile palps (Figure 3D, E): palps asymmetrical, right palp plumper than left one. Right palp with second subapical structure present, but much shorter than the left one. Left palp elongated with only one subapical structure observed. Same palp dorsally with one chitinous extension

Walking leg (Figure 2E): basal segment without any seta. First endopodal segment with one distal seta. Second and third endopodal segment partially fused with no medial setae present. Distal seta short. Terminal segment with two short setae and one claw which 1.5 times longer than three distal segments combined. Length ratios of three endopodal segments $5.5: 4.3: 1$.

Cleaning log (Figure 2B): basal segment with all three setae present. Seta Te on first endopodal segment present, as well as seta $\mathrm{Tg}$, while $\mathrm{Tf}$ seta on second endopodal segment absent. Terminal segment with two long (Th2 and Th3) setae and one short seta (Th1). Length ratio of three setae 1 : $1.6: 2$.

Caudal ramus (Figure 2D): posterior seta absent, anterior seta present and about 2.5 times shorter than anterior claw. Both claws without prominent spines, only gently serrated. Length ratios between anterior margin, anterior claw and posterior claw equaling $1.8: 1: 1$

Hemipenis (Figure 1D): lobe "a" triangular and medially positioned, with pointed distal margin, lobe " $b$ " rounded. Internal canals with double coils. Lobe "g" prominent and wounded.

Female. Length of carapace $0.63 \mathrm{~mm}$. Greatest height $50 \%$ of length (Figure 1C). Carapace appearance similar to male, except for small convex part around mouth region, and slightly more setae on carapace surface.

Antenna (Figure $3 \mathrm{~A}$ ): setae $\mathrm{z} 1$ and $\mathrm{z} 2$ present, seta 23 absent. All terminal claws long, G1, G2 and G3 2.2 times longer than first endopodal segment. Claw GM on terminal segment also long and 1.9 times longer than first endopodal segment. Only one " $\mathrm{t}$ " seta observed.

First thoracopod (Figure 3C): three setae on exopod, only one "a" seta present.

Caudal ramus and genital ficld (Figure 3B): Length ratios between anterior margin, anterior and posterior claw equaling 1.85: 1: 1. Genital field rounded and without any protrusion.

Antennula, maxillula, mandibula, walking and cleaning legs same as in male.

\section{Remarks and affinities}

The new species can be easily distinguished from the remaining species of the Cantonopsis species by the 6-segmented antennula and incompletely divided penultimate segment of the walking leg. The absence of a seta on the basal segment of the walking leg places Camtonopsis linnali within the subgenus Abcandonopsis Karanovic 2004. Almost all of the species of this 


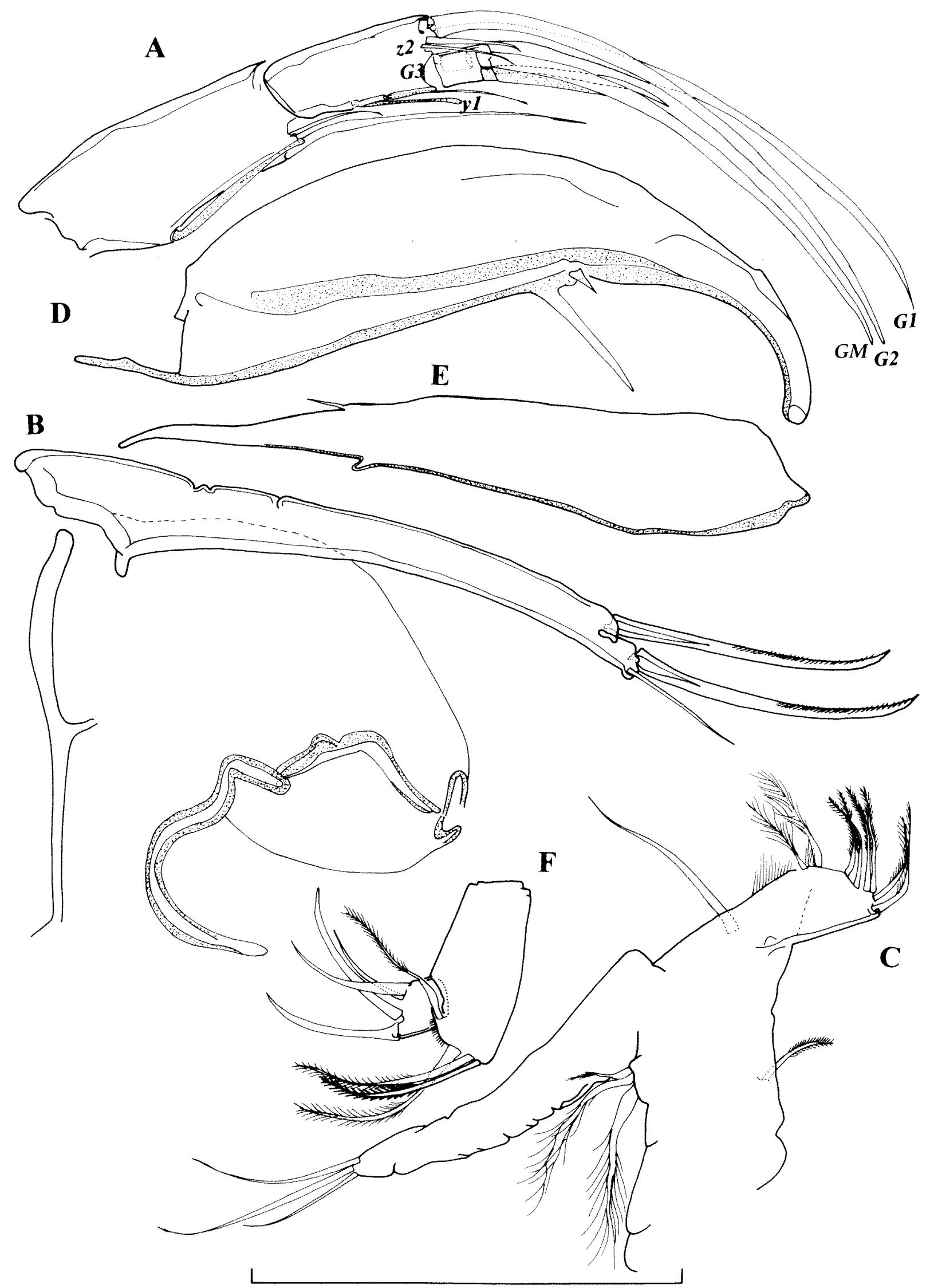

Figure 3 Candonopsis limnaei sp. nov., A-C, female $(0.63 \mathrm{~mm})$; D-F, holotype male: $\mathrm{A}$, antenna; $\mathrm{B}$, caudal ramus with genital field; $C$, first thoracopod; D, right prehensile palp; $E$, left prehensile palp; $F$, maxillular palp. Scale lines $=0.1 \mathrm{~mm}$. 
subgenus lack the $\mathrm{Tf}$ seta on the penultimate segment of the walking leg, except for $C$. (A.) pilbarae Karanovic 2007. The latter species and two species from the Pilbara region, $C$. (A.) dedeckeri Karanovic 2007, and C. (A.) inaffecta Karanovic 2007 , have ornamented surface of the carapace, while it is smooth in the new species. A smooth carapace is also a characteristic of another species from the Murchison region, C. (A.) williami Karanovic and Marmonier 2002, as well as of both species from the Kimberly region: $C$. (A.) aula Karanovic 2004 and C. (A.) indoles Karanovic 2004. These three species, as well as the new one, have pronouncedly asymmetrical valves (left one being considerably larger than the right one), while in the species from the Pilbara this is not the case. In addition to the 6-segmented antennula and undivided penultimate segment on the walking leg, C. (A.) linnaei differs from C. (A.) williami, $C$. (A.) indoles, and C. (A.) aula also by the presence of the $\mathrm{d} 2$ seta on the basal segment of the cleaning leg. Candonopsis aula has only one claw on the caudal ramus.

\section{Etymology}

The species name is dedicated to Carolus Linnaeus in celebration of the tercentenary of his birth in 1707 and the $250^{\text {th }}$ anniversary of Systema Naturae.

\section{Key to Australian Candonopsis species}

1. Basal segment of walking leg without seta ......2 Basal segment of walking leg with one seta.....8

2. Antenula 6-segmented .. Candonopsis (A.) limnaei sp. nov.

Antennula 7-segmented 3

3. Caudal ramus with only one claw. Candonopsis (A.) aula Karanovic 2004

Caudal ramus with two claws. ...4

4. Seta "d2" on basal segment of cleaning leg absent......................................................... 5

- Seta "d2" on basal segment of cleaning leg present.....

5. Carapace ornamented ventrally, and the greatest height in front of the middle Candonopsis (A.) inaffecta Karanovic 2007

Carapace smooth and greatest height around the middle or behind.

6. Dorsal margin of the carapace straight, lobe " $a$ " on the hemipenis rounded, second and third endopodal segments of the cleaning leg incompletely divided....

........ Candonopsis (A.) indoles Karanovic 2004

Dorsal margin of the carapace rounded, lobe " $a$ " of the hemipenis pointed distally, second and third endopodal segments on the cleaning leg completely divided Candonopsis (A.)

williami Karanovic and Marmonier 2002

7. Seta Tf on the cleaning leg absent

.... Candonopsis (A.) dedeckeri Karanovic 2007

- Seta Tf on the cleaning leg present....

......... Candonopsis (A.) pilbara' Karanovic 2007

8. Posterior claw on the caudal ramus reduced....

...Candonopsis (C.) westanstralionsis Karanovic and Marmonier 2002

Posterior claw on the caudal ramus normally developed.....

\section{9}

9. Carapace heavily omamented with shallow but well expressed pits Candonopsis (C.)

kimberleyi Karanovic and Marmonier 2002

Carapace not heavily ornamented. 10

10. Valves asymmetrical, dorsally right valve overlaps left one with a flange...................11

Valves symmetrical, no flange on the right valve developed

.. Candonopsis (C.) temis (Brady 1886)

11. Claws on the caudal ramus subequal, or anterior one slightly longer than posterior.... ..Candonopsis (C.) murchisoni Karanovic and Marmonier 2002

Anterior claw on the caudal ramus at least 1.4 times longer than posterior one

..Candonopsis (C.)

dami Karanovic and Marmonier 2002

\section{DISCUSSION}

The tribe Candonopsini today comprises 38 valid Recent species, classified into five genera and one subgenus. The most diversified is the genus Candonopsis with 28 living species, followed by Cubacandona Broodbakker 1983, with four species, Caribecandona Broodbakker 1983 , with three species, Marococandona Marmonier, Boulal and Idbennacer 2005, with two species, and Pionererandonopsis Karanovic 2005a, with only one species. The last three genera are stygobionts while Cubacandona and Candonopsis have both subterranean and surface water species (see Karanovic 2004). Among the Candonopsini genera, fossilized species are known only for Candonopsis, and it is considered that the earliest fossils date back to the Miocene (Danielopol 1980b). Partly because the fossil sediments of Eurasia are better investigated, data regarding the fossil Candonopsis mostly relate to this area (see Janz 1992; Krstic 2006). Fossils of lacustrine sediments in Australia are very 
poorly known, and not a single fossil species of the genus Candonopsis or any of the genera of the tribe Candonopsini has been described from this continent. According to the present day ecological preferences of the species and the zoogeography of the genus, it may be that further research of lacustrine sediments in Australia may reveal some of the ancestors of the present day Candonopsini fauna. With the exception of $C$. tenuis, all the other Australian species of the genus are stygobionts. They may have started to colonize subterranean waters from the above-ground freshwater during the Miocene and Pliocene aridity (Frakes 1999). Most of the species have several morphological reductions, as a consequence of adaptation to the subterranean environment, and this is more pronounced in the subgenus Abcandonopsis Karanovic 2004 than in the nominotypical one. The morphological reductions are evident more so in the other four Candonopsini genera. For example, Pionecrandonopsis hancocki Karanovic 2007 has a 5-segmented antennula as well as one of the species of the genus Marococandona and all Caribecandona, in which the caudal ramus has only one claw. Karanovic (2005a) performed a cladistic analysis of the tribe Candonopsini, including all 32 species known at the time. The results clearly cluster the genus Pioneercandonopsis from Queensland with the South American genera, Caribecandona and Cubacandona, and not with the Australian Candonopsini. One, still undescribed, genus from northern New South Wales is also more closely related to the South American genera and the genus from Queensland than to the rest of Candonopsini from Western Australia, Africa and Europe. However, discussions on the zoogeography of the Australian subterranean ostracods, and other stygobiont invertebrates, will have to wait for more thorough investigations on these ecosystems in Australia. The gap in knowledge of the stygofauna of Australia (but also of Africa and South America) is not only a problem for biogeographical and evolutionary reconstruction, but also for groundwater management. This problem is emphasized especially in Australia, where mining processes often involve using water and lowering the water table, or completely dewatering calcrete bodies, for the purpose of further mineral explorations (Eberhard et al. 2004).

\section{ACKNOWLEDGEMENTS}

I would like to thank Dr Mark Harvey for inviting me to participate in this special edition of the Records of the Western Australian Museum, and to the School of Zoology, University of Tasmania, for granting me the status of Honorary
Research Associate. I am also very grateful to all the employees of the consulting agency Outback Ecology (and especially to Ms Veronica Campagnia and Ms Erin Thomas) for collecting and sending to me this ostracod material for identification.

\section{REFERENCES}

Brady, G. S. (1886). Notes on freshwater Entomostraca from South Australia. Proceedings of the Zoological Society, London 1: 82-93.

Broodbakker, N. W. (1983). The subfamily Candoninae (Crustacea, Ostracoda) in the West Indies. Bijdragen tot de Dierkunde 53: 103-120.

Broodbakker, N. W. and Danielopol, D. L. (1982). The chaetotaxy of Cypridacea (Crustacea, Ostracoda) limbs: proposals for a descriptive model. Bijdragen tot de Dierkunde 52: 103-120.

Danielopol, D. L. (1969). Recherches sur la morphologie de l'organe copulateur mâle chez quelques ostracodes du genre Candona Baird (fam. Cyprididae Baird). In: Neale, J. W. (ed.), The taxonomy, morphology and ecology of recent Ostracoda: 136-153. Oliver and Boyd Ltd: Edinburgh.

Danielopol, D. L. (1980a). Deux espéces hypogées du genre Candonopsis (Ostracoda, Candoninae) du sud de la France et de Cuba. Vie et Milieu 30: 315-323.

Danielopol, D. L. (1980b). An essay to assess the age of the freshwater interstitial Ostracods of Europe. Bijdragen tot de Dierkunde 50: 243-291.

Eberhard, S. M., Halse, S. A., Scanlon, M. D., Cocking, J. S. and Barron, H. J. (2004). Assessment and conservation of aquatic life in the subsurface of the Pilbara region, Western Australia. In: Gilbert, J. (ed.), World subterranean biodiversity. Pp. 61-68. Proceedings of the International Symposium $\left(8^{\text {th }}-10^{\text {th }}\right.$ December 2004) Villeurbanne, France, Université Claude Bernant of Lyon 7, PASCALIS European Research Programme.

Frakes, J. K. (1999). Evolution of Australian environments. Flora of Australia ( $2^{\text {nd }}$ edition) 7: 163-203. CSIRO, Collingwood.

Janz, H. (1992). Die miozänen Süsswasserostracoden des Steinheimer Beckens (Schwäbische Alb, Süddeutschland). Stuttgarter Beiträge zur Naturkunde, Serie B (Geologie und Paläontologie) 183: 1-117.

Karanovic, I. (2004). Towards a revision of Candoninae (Crustacea, Ostracoda): on the genus Candonopsis Vávra, with description of new taxa. Subterranean Biology 2: 91-108.

Karanovic, I. (2005a). A new Candoninae genus (Crustacea: Ostracoda) from subterranean waters of Queensland, with a cladistic analysis of the tribe Candonopsini. Memoirs of the Queensland Museum 50: 303-319.

Karanovic, 1. (2005b). Comparative morphology of the Candoninae antennula, with remarks on the ancestral state in ostracods (Crustacea, Ostracoda) and proposed new terminology. Spixiana 28: 141-160.

Karanovic, I. (2007). Candoninae (Ostracoda) from the Pilbara region in Western Australia. Crustaceana Monographs 7: 1-433. 
Karanovic, I. and Marmonier, P. (2002). On the genus Candonopsis (Crustacea: Ostracoda: Candoninae) in Australia, with a key to the world recent species. Annales de Limnologie 38: 199-240.

Krstic, N. (2006) Pliocene Ostracodes of the Paludinian Beds in the Pannonian Plain, Serbian Part. Herald of the Natural History Museum, Belgrade, Special Publications: $1-409$.

Kaufmann, A. (1900). Cypriden und Darwinuliden der Schweiz. Revue Suisse de Zoologie 8: 209-423.

Klie, W. (1932). Die Ostracoden der Deutschen Limnologischen Sunda-Expedition. Archiv fiir Hydrobiologic, Suppl.-Bd. 11: "Tropischen Binnengewässer" 3: 447-502.

Marmonier, P. M. Boulal, and Idbennacer, B. (2005). Marococandona, a new genus of Candoninae (Crustacea, Ostracoda) from southern Morocco: morphological characteristics and ecological requirements. Amales de Limnologie 41: 57-71.

Martens, K. (1987). Homology and functional morphology of the sexual dimorphism in the antenna of Sclerocypris Sars, 1924 (Crustacea, Ostracoda, Megalocypridinae). Bijdragen tot de Dierkunde 57: 183-190.
Meisch, C. (1996). Contribution to the taxonomy of Psendocandoma and four related genera, with the description of Schellencandona nov. gen.; a list of the Candoninae genera, and a key to the European genera of the subfamily (Crustacea, Ostracoda). Bulletin de la Societe des Naturalistes Luxcmbourgeois 97, 211-237.

Sars, G. O. (1896). On fresh-water Entomostraca from the neighborhood of Sydney, partly raised from dried mud. Archiv for Mathematik of Naturoidenskab 18: 1-81.

Stock, J. H and Von Vaupel Klein, J. C. (1996). Mounting media revisited: the suitability of Reyne's fluid for small crustaceas. Crustacenua 69: 794-798.

Vávra, W. (1891). Monographie der Ostracoden Böhmens. Archio der Naturaissenschaftlichen Landesdurchforschung zon Böhmen 8: 1-116

Mamuscript receiced 12 March 2008; accepted 29 July 2008. 